OPEN ACCESS

Edited by:

Mesenbet Yibeltal,

Bahir Dar University, Ethiopia

Reviewed by:

Réka Kiss,

Hungarian Academy of Sciences,

Hungary

Longyu Hou,

Institute of Botany (CAS), China

*Correspondence:

Hong-Yuan Ma

mahongyuan@iga.ac.cn

Lei Wang

Wangegiwang@ms.xjb.ac.cn

Specialty section: This article was submitted to Conservation and Restoration

Ecology,

a section of the journal Frontiers in Environmental Science

Received: 01 May 2021 Accepted: 02 September 2021 Published: 15 September 2021

Citation:

Zhao D-D, Ma H-Y, Wang L, Li S-Y, Qi W-W, Ma M-Y and Xia J-B (2021)

Effects of Water and Nitrogen Addition

on the Seed Yield and Germination Characteristics of the Perennial Grass

Leymus chinensis (Trin.) Tzvel.

Front. Environ. Sci. 9:704097.

doi: 10.3389/fenvs.2021.704097

\section{Effects of Water and Nitrogen Addition on the Seed Yield and Germination Characteristics of the Perennial Grass Leymus chinensis (Trin.) Tzvel}

\author{
Dan-Dan Zhao ${ }^{1,2}$, Hong-Yuan $\mathrm{Ma}^{1 *}$, Lei Wang ${ }^{3 *}$, Shao-Yang $\mathrm{Li}^{1}$, Wen-Wen $\mathrm{Qi}^{1}$, \\ Meng-Yao $\mathrm{Ma}^{1}$ and Jiang-Bao Xia ${ }^{2}$
}

${ }^{1}$ Northeast Institute of Geography and Agroecology, Chinese Academy of Sciences, Changchun, China, ${ }^{2}$ Shandong Key Laboratory of Eco-Environmental Science for Yellow River Delta, Binzhou University, Binzhou, China, ${ }^{3}$ State Key Laboratory of Desert and Oasis Ecology, Xinjiang Institute of Ecology and Geography, Chinese Academy of Sciences, Urumai, China

The reproductive characteristics of plants are likely affected by climate change e.g., changes in precipitation patterns and nitrogen deposition, but few studies have examined the effects of these ecological agents of selection on the seed yield and germination characteristics of perennial grasses. Here, we conducted a multiple-year pot experiment with Leymus chinensis, a common perennial grass in the eastern region of the Eurasian steppe zone, which was grown under three water treatments with and without nitrogen addition. The seed yield of $L$. chinensis increased with precipitation and was highest $(7.0 \mathrm{~g} / \mathrm{pot})$ under $747 \mathrm{~mm}$ of precipitation with nitrogen addition $\left(10.5 \mathrm{~g} / \mathrm{m}^{2}\right)$. Seed yield was positively correlated with heading number, tiller number, and grain number per spike, and the heading number was a critical factor affecting seed yield. Seed germination percentage and the time to obtain 50\% germination were affected by environmental cues experienced by the mother plants.

Keywords: Leymus chinensis, precipitation, nitrogen deposition, sexual reproduction, seed yield, seed germination

\section{INTRODUCTION}

Grasslands are among the most widely distributed terrestrial biomes globally, covering ca. 52.54 million $\mathrm{km}^{2}$ of the terrestrial surface (Zhao et al., 2020). Grasslands play an important role in regional climates, biodiversity, conservation, the provision of ecosystem services, and socio-economic development (Zhao et al., 2015; Han et al., 2018; Nerlekar and Veldman, 2020). Grasslands have become seriously degraded because of climate change and human activities (Andrade et al., 2015; Shen et al., 2016; Wick et al., 2016; Zhou et al., 2020). The continual degradation of grasslands has caused a series of problems, including grassland desertification, biodiversity loss, and the decrease of carbon sinks capacity reduction, and these problems pose a threat to animal husbandry, ecological security, and sustainable development. The restoration of degraded grasslands thus require urgent attention (Man et al., 2016; Ma et al., 2018).

Given that the atmospheric deposition of biologically active nitrogen $(\mathrm{N})$ has increased dramatically over the past few decades and precipitation patterns have changed, there has been increased research interest in examining the effects of $\mathrm{N}$ deposition and precipitation on the growth and reproduction of grass (Duan et al., 2019; Zhao et al., 2019). The addition of $\mathrm{N}$ has been shown to increase the height, population density, $\mathrm{N}$ concentration in tissues, photosynthetic rate, and wateruse efficiency of plants (Pan et al., 2005; Ren et al., 2014). Ochoa-Hueso et al. (2014) suggested that 
increases in precipitation can enhance plant productivity and thus potentially food production in water-limited ecosystems. Most studies examining the effects of elevated $\mathrm{N}$ deposition and altered precipitation on grasslands have focused on net primary productivity or vegetative plant reproduction. By contrast, few studies have examined the effects of $\mathrm{N}$ deposition and precipitation on the sexual reproduction of plants (Wu et al., 2011; Gajić et al., 2018; Huang et al., 2019; Zhao et al., 2019).

Regulation of water and $\mathrm{N}$ is one of the most effective methods for increasing the seed yield of grasses. Some studies have found that water and $\mathrm{N}$ can increase the supply of nutrients in plants, prevent floret degeneration, and increase the number of seeds (Islam et al., 2018; Liu et al., 2019; Wang et al., 2020). Kunstler et al. (2016) reported that a lack of precipitation reduced the number of plant tillers and the differentiation of spikes and florets. Li et al. (2015) found that the seed productivity of artificial grassland was significantly higher than that of natural grassland because of differences in nutrient conditions. Yang, (1989) reported that water and $\mathrm{N}$ can affect the development of seed-bearing organs in the ear of Leymus chinensis, and the residual effect of fertilization can enhance the seed yield of plants in the second year. Wang et al. (2013) found that $\mathrm{N}$ addition can increase the number of reproductive branches and promote the seed production of L chinensis. Its ability to utilize and compete for nutrients and water resources depends on the stage of seed germination (Ghaderi-Far et al., 2010; Ma et al., 2012). However, few studies have examined the effects of nutrient addition and precipitation changes on the seed germination of maternal plants in semi-arid grassland.

Leymus chinensis (Trin.) Tzvel (L. chinensis) is the dominant perennial, rhizomatous grass in the eastern region of the Eurasian steppe zone, including the Songnen grassland, which features an arid climate and has soils that are high $\mathrm{pH}$ and low in $\mathrm{N}$ (Wang et al., 2019). L. chinensis is considered the most appropriate grass for restoring degraded grasslands and establishing new grasslands in marginal areas. L. chinensis has a low heading percentage, low seed setting percentage, and low germination percentage, which severely limit its further utilization and seed yield (Shi et al., 2017). Thus, the low seed production capacity of L. chinensis is the main factor limiting its ability to be used for the establishment of large-scale artificial grasslands (Zhou and Yang, 2006; Wang et al., 2010).

Our previous study has shown that the aboveground biomass of $L$. chinensis increases with precipitation, and the aboveground biomass of $L$. chinensis was highest under $10.5 \mathrm{~g} / \mathrm{m}^{2} \mathrm{~N}$ addition and $747 \mathrm{~mm}$ of precipitation. Short-term $\mathrm{N}$ addition significantly affects leaf physiological traits but has no effect on morphological traits (Zhao et al., 2020). Whether the seed yield and germination characteristics of $L$. chinensis are altered after multiple years of water and $\mathrm{N}$ treatments has not yet been studied. Here, we characterized the effects of different water and $\mathrm{N}$ treatments on the sexual reproduction ability and seed germination of $L$. chinensis. We hypothesized that variation in the amount of precipitation and $\mathrm{N}$ addition would 1) alter the seed setting characteristics of L. chinensis and 2) affect the germination characteristics of the maternal plant seeds.

\section{MATERIALS AND METHODS}

\section{Experimental Design and Sampling}

The pot experiment was conducted in a movable rain shelter in Changchun, Jilin Province $\left(124^{\circ} 18^{\prime}-127^{\circ} 02^{\prime} \mathrm{E}, 43^{\circ} 05^{\prime}-45^{\circ} 15^{\prime} \mathrm{N}\right.$, altitude of 250-350 masl). The site's mean annual temperature is $4.9^{\circ} \mathrm{C}$, with an average temperature of $23^{\circ} \mathrm{C}$ in July and $-16.4^{\circ} \mathrm{C}$ in January. The area features a temperate continental climate with a mean annual precipitation of $498.0 \mathrm{~mm}$, maximum annual precipitation of $754.0 \mathrm{~mm}$ (1956, 50\% higher than the mean), and minimum of $244.1 \mathrm{~mm}$ (1982, 50\% lower than the mean) for the period 1953-2012. The experimental field was covered with black soil, which had a $\mathrm{pH}$ of 7.12 , electrical conductivity of $0.73 \mathrm{dS} / \mathrm{m}$, and soil organic carbon, $\mathrm{N}$, and phosphorus (P) concentrations of $2.83 \%, 1.37 \mathrm{~g} / \mathrm{kg}$, and $0.67 \mathrm{~g} / \mathrm{kg}$, respectively (Zhao et al., 2019). The plastic plant pots (diameter: $30 \mathrm{~cm}$, height: $30 \mathrm{~cm}$ ) were filled with sieved soil from the $0-20 \mathrm{~cm}$ layer near the experimental field. Ten seedlings of $L$. chinensis were transplanted to each pot uniformly on June 01, 2016. Regular watering and weeding were carried out to ensure the normal growth of $L$. chinensis.

The water and $\mathrm{N}$ treatments began on June 01,2017 . There were three precipitation gradients and two nutrient levels (each with three replicates, 18 pots in total) to explore the effects of water, $\mathrm{N}$, and the water $\times \mathrm{N}$ interaction on the seed yield and germination characteristics of $L$. chinensis. The three precipitation gradients were mean annual precipitation $\left(498 \mathrm{~mm}, \mathrm{~W}_{2}\right), 150 \%$ mean annual precipitation $(747 \mathrm{~mm}$, $\left.\mathrm{W}_{3}\right)$, and $50 \%$ mean annual precipitation $\left(249 \mathrm{~mm}, \mathrm{~W}_{1}\right)$. Underground water was used for irrigation (once every other day), and the concentrations of $\mathrm{N}, \mathrm{P}$, and potassium in underground water were below the limits of detection. The irrigation amount was 96, 193, and $289 \mathrm{ml} /$ pot for $\mathrm{W}_{1}, \mathrm{~W}_{2}$, and $\mathrm{W}_{3}$, respectively. The two nutrient levels were control $\left(\mathrm{N}_{0}\right)$ and $\mathrm{N}$ addition $\left(\mathrm{N}_{1}\right)$. The amount of $\mathrm{N}$ was based on recommendations for alleviating nitrogen limitation in typical steppe (Bai et al., 2008; Bai et al., 2014). To avoid natural $\mathrm{N}$ input from wet deposition, all of $L$. chinensis plants were covered by a transparent polyvinylchloride roof on rainy days.

At the seed maturity stage on August 15, 2018, we determined the tiller number per pot and heading number per pot and measured the spike length, grain number per spike, and seed setting rate from nine randomly selected samples from each pot.

\section{Germination Experiment}

The germination test was carried out in an incubator (Harbin, China) using 9-cm diameter Petri dishes lined with two layers of filter paper that were saturated with $6 \mathrm{ml}$ of distilled water. The incubation regime consisted of alternating cycles of $12 \mathrm{~h}$ of light (fluorescent and incandescent white light of $54 \mu \mathrm{molm}^{-2} \mathrm{~s}^{-1}$ ) and high temperature $\left(28^{\circ} \mathrm{C}\right)$ and $12 \mathrm{~h}$ of darkness and low temperature $\left(16^{\circ} \mathrm{C}\right)$. Water was added to the dishes when necessary to ensure that they were continuously moist. The dishes were distributed randomly in the incubator, and their positions changed daily. Each water and $\mathrm{N}$ treatment was replicated nine times, with 25 seeds were used in each 
TABLE 1 | Results of two-way ANOVAs for the effects of water, nitrogen and their interactions on yield components of $L$. chinensis.

\begin{tabular}{|c|c|c|c|c|c|c|c|c|c|c|c|c|c|}
\hline \multirow[t]{2}{*}{ Factor } & \multirow[t]{2}{*}{ d.f. } & \multicolumn{3}{|c|}{ Grain number/spike } & \multicolumn{3}{|c|}{ Seed setting rate (\%) } & \multicolumn{3}{|c|}{ Thousand seed weight (g) } & \multicolumn{3}{|c|}{ Seed yield (g/pot) } \\
\hline & & MS & $\boldsymbol{F}$ & $p$ & MS & $\boldsymbol{F}$ & $p$ & MS & $\boldsymbol{F}$ & $p$ & MS & $\boldsymbol{F}$ & $p$ \\
\hline Water (W) & 2 & 2882.228 & 227.434 & 0.004 & 1353.127 & 41.123 & 0.024 & 0.428 & 16.870 & 0.056 & 44.581 & 129.712 & $<0.001$ \\
\hline Nitrogen $(\mathrm{N})$ & 1 & 32.895 & 2.596 & 0.248 & 389.087 & 11.825 & 0.075 & 0.205 & 8.080 & 0.105 & 3.727 & 10.844 & 0.006 \\
\hline $\mathrm{W} \times \mathrm{N}$ & 2 & 12.673 & 0.210 & 0.814 & 32.905 & 0.512 & 0.612 & 0.025 & 0.166 & 0.849 & 2.264 & 6.588 & 0.012 \\
\hline
\end{tabular}

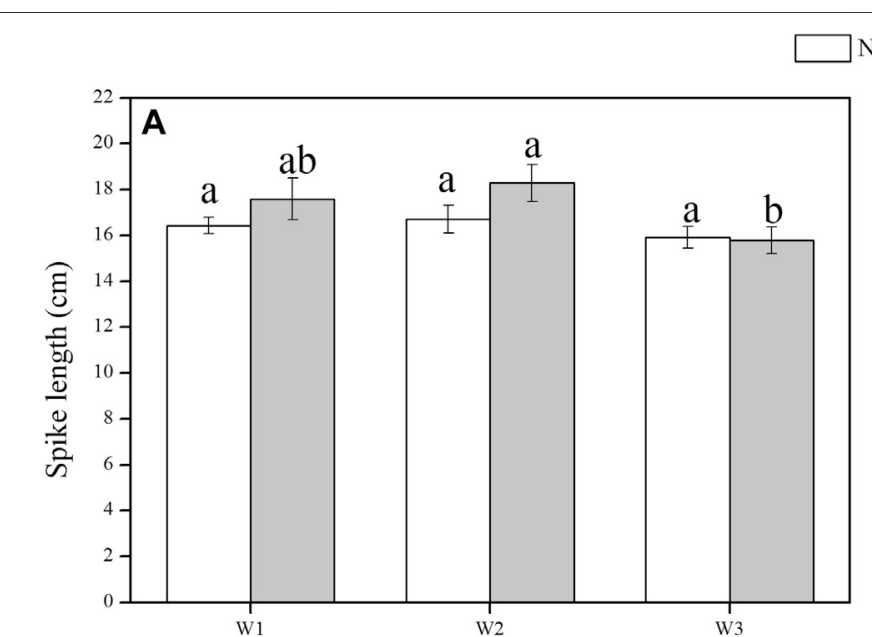

No $\square$ N1
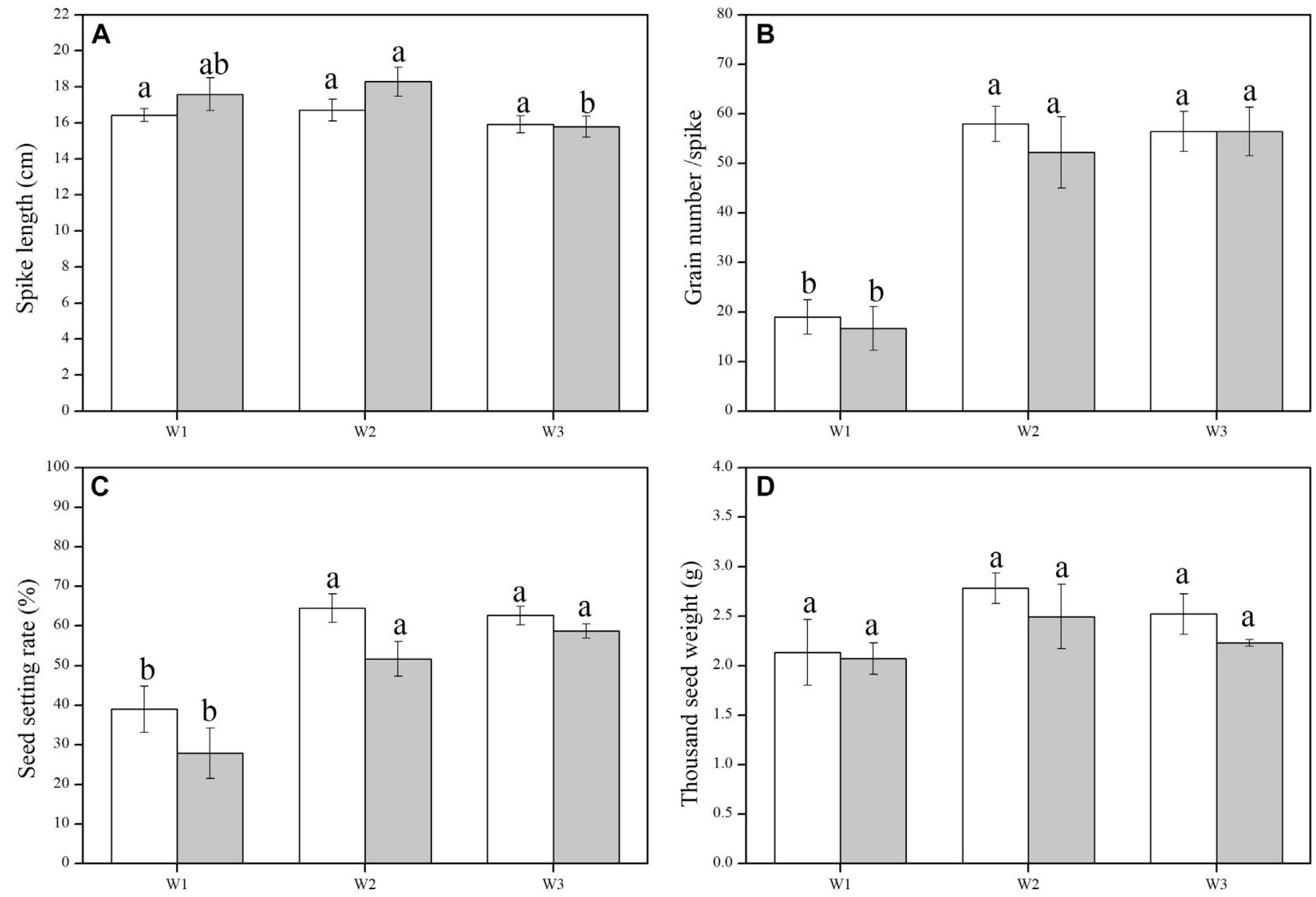

Water treatment

FIGURE 1 | Effects of water and nitrogen on yield components of $L$. chinensis (mean $\pm \mathrm{SE}$ ). $\mathrm{N}_{0}$, control, without $\mathrm{N}$ application; $\mathrm{N}_{1}, \mathrm{~N}$ applied as urea at $10.5 \mathrm{~g} \mathrm{~N} / \mathrm{m}^{2}$; $W_{1}, 50 \%$ mean annual precipitation $\left(249 \mathrm{~mm}\right.$ ) (irrigation amount: $96 \mathrm{ml}$ per pot); $W_{2}$, mean annual precipitation (498 mm) (irrigation amount: $193 \mathrm{ml}$ per pot); and $W_{3}$, $150 \%$ mean annual precipitation $(747 \mathrm{~mm}$ ) (irrigation amount: $289 \mathrm{ml}$ per pot). Different lowercase letters indicate significant differences $(p<0.05)$ among water treatments at the same level of $\mathrm{N}$ addition.

replication. Seeds were considered to be germinated upon emergence of the radicle. Germination was recorded every day for 28 days. The time to $50 \%$ germination (in days) was calculated from the germination times of all germinated seeds.

Germination percentage (GP) was calculated using the equation:

$$
G P=(\mathrm{n} / \mathrm{N}) \times 100
$$

where $\mathrm{n}$ is the number of germinated seeds at the end of the test, and $\mathrm{N}$ is the total number of seeds kept for germination.

The time to obtain $50 \%$ germination $\left(\mathrm{T}_{50}\right)$ was calculated using the equation (Farooq et al., 2005):

$$
T_{50}=\mathrm{ti}+\frac{\left(\frac{N}{2}-N i\right)(t j-t i)}{(\mathrm{Nj}-\mathrm{Ni})}
$$




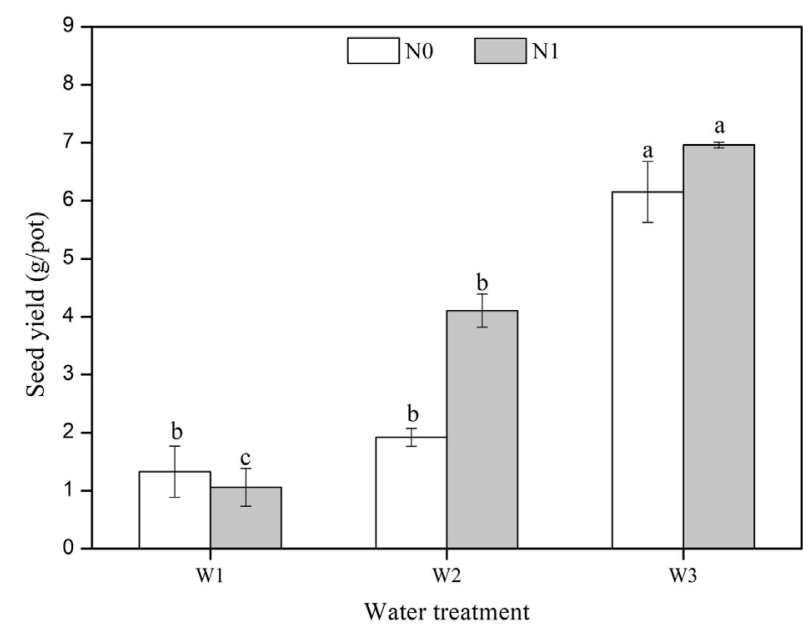

FIGURE 2 | Effects of water and nitrogen on seed yield of $L$. chinensis (mean $\pm \mathrm{SE}$ ). $\mathrm{N}_{0}$, control, without $\mathrm{N}$ application; $\mathrm{N}_{1}, \mathrm{~N}$ applied as urea at $10.5 \mathrm{~g}$ $\mathrm{N} / \mathrm{m}^{2} ; \mathrm{W}_{1}, 50 \%$ mean annual precipitation $(249 \mathrm{~mm}$ ) (irrigation amount: $96 \mathrm{ml}$ per pot); $W_{2}$, mean annual precipitation $(498 \mathrm{~mm})$ (irrigation amount: $193 \mathrm{ml}$ per pot); and $\mathrm{W}_{3}, 150 \%$ mean annual precipitation $(747 \mathrm{~mm}$ ) (irrigation amount: $289 \mathrm{ml}$ per pot). Different lowercase letters indicate significant differences $(p<0.05)$ among water treatments at the same level of $\mathrm{N}$ addition.

where $\mathrm{N}$ is the final number of germinated seeds, $\mathrm{Nj}$ and $\mathrm{Ni}$ are the cumulative numbers of seeds germinated by adjacent counts at times tj and ti, respectively, when $\mathrm{Ni}<\mathrm{N} / 2<\mathrm{Nj}$.

\section{Statistical Analyses}

Generalized linear model (GLM) was used to analyze the effects of water, $\mathrm{N}$, and the water $\times \mathrm{N}$ interaction on seed yield, yield components, GP and $\mathrm{T}_{50}$, where water and $\mathrm{N}$ served as fixed factors and block as a random effect. Analysis of variance, followed by Duncan's test, was used to compare means among treatments. Pearson's correlation coefficients were used to analyze the relationships between yield components and other related characters. Differences were considered statistically significant at $p$ values of 0.05 . All the analyses were performed in SPSS 20.0 software program (SPSS Inc., Chicago, Illinois, United States).

\section{RESULTS}

\section{Seed Yield and Components}

The grain number per spike and seed setting rate were significantly affected by water $(F=227.434, p<0.01 ; F=41.123, p<0.05$; Figures 1B,C; Table 1). There was no significant difference in the spike length between $\mathrm{N}$ treatments under the same precipitation treatment (Figure 1A). Under $\mathrm{N}_{1}$, the spike length of L. chinensis was $13.7 \%$ lower under $\mathrm{W}_{3}$ compared with $\mathrm{W}_{2}$. Grain number per spike and seed setting rate were lower under $\mathrm{W}_{1}$ than under $\mathrm{W}_{2}$ and $\mathrm{W}_{3}$. Under the same precipitation treatment, the seed setting rate and thousand seed weight of $L$. chinensis were higher under $\mathrm{N}_{0}$ than $\mathrm{N}_{1}$ (Figures 1C,D).

The seed yield per pot of $L$. chinensis was significantly affected by water, $\mathrm{N}$, and the water $\times \mathrm{N}$ interaction $(F=129.712, p<0.001$;
TABLE 2 | The correlation among yield components and other related characters.

\begin{tabular}{lccccc}
\hline Factor & $\mathbf{X}_{\mathbf{1}}$ & $\mathbf{X}_{\mathbf{2}}$ & $\mathbf{X}_{\mathbf{3}}$ & $\mathbf{X}_{\mathbf{4}}$ & $\mathbf{X}_{\mathbf{5}}$ \\
\hline$X_{2}$ & $0.507^{\star}$ & - & - & - & - \\
$X_{3}$ & -0.166 & -0.427 & - & - & - \\
$X_{4}$ & 0.335 & -0.065 & -0.053 & - & - \\
$X_{5}$ & 0.137 & -0.273 & 0.143 & $0.583^{\star}$ & - \\
$Y$ & $0.566^{\star}$ & $0.594^{* *}$ & -0.267 & $0.701^{* *}$ & 0.192
\end{tabular}

$X_{1}$, Tiller number; $X_{2}$, Heading number; $X_{3}$, Spike length; $X_{4}$, Grain number/spike; $X_{5}$, Thousand seed weight; $Y$, Seed yield. Correlation coefficients calculated by the Pearson two-tailed test; *and ${ }^{* *}$ indicate significant correlation at the 0.05 and 0.01 levels, respectively.

TABLE 3 | Results of two-way ANOVAs for the effects of water, nitrogen and their interactions on germination and $T_{50}$ of $L$. chinensis.

\begin{tabular}{lccccccc}
\hline Factor & d.f. & \multicolumn{3}{c}{$\begin{array}{c}\text { Germination } \\
\text { percentage (\%) }\end{array}$} & & \multicolumn{3}{c}{$\mathbf{T}_{\mathbf{5 0}}$ (d) } \\
\cline { 3 - 8 } & & MS & $\boldsymbol{F}$ & $\boldsymbol{p}$ & MS & $\boldsymbol{F}$ & $\boldsymbol{p}$ \\
\hline Water (W) & 2 & 134.222 & 1.189 & 0.457 & 18.841 & 3.318 & 0.232 \\
Nitrogen (N) & 1 & 0.889 & 0.008 & 0.937 & 9.315 & 1.64 & 0.329 \\
W $\times$ N & 2 & 112.889 & 4.536 & 0.034 & 5.679 & 1.778 & 0.211
\end{tabular}

$F=10.844, p<0.01 ; F=6.588, p<0.05$; Table 1). Seed yield significantly increased with precipitation. The highest seed yield was observed under $\mathrm{N}_{1} \mathrm{~W}_{3}(7.0 \mathrm{~g} / \mathrm{pot})$. Plants under $\mathrm{N}_{1} \mathrm{~W}_{2}$ produced two-fold more seeds than the plants under $\mathrm{N}_{0} \mathrm{~W}_{2}$. The seed yield was $13.2 \%$ higher under $\mathrm{N}_{1} \mathrm{~W}_{3}$ than under $\mathrm{N}_{0} \mathrm{~W}_{3}$ (Figure 2). The water $\times \mathrm{N}$ interaction had a positive effect on the seed yield of L. chinensis.

Significant positive correlations were observed between seed yield and tiller number $\left(\mathrm{R}^{2}=0.566, p<0.05\right)$. There was a significant positive correlation between seed yield and heading number $\left(\mathrm{R}^{2}=0.594, p<0.01\right.$, Table 2$)$. Tiller number had a smaller effect on seed yield compared with heading number. There was a significant positive correlation between tiller number and heading number $\left(\mathrm{R}^{2}=0.507, p<0.05\right)$. Significant positive correlations were observed between seed yield and grain number per spike $\left(\mathrm{R}^{2}=0.701, p<0.01\right)$. There was a negative, but nonsignificant, correlation between spike length and seed yield. Significant positive correlations were observed between thousand seed weight and grain number per spike $\left(\mathrm{R}^{2}=0.583\right.$, $p<0.05)$.

\section{Seed Germination}

The GP of L. chinensis was significantly affected by the water $\times \mathrm{N}$ interaction $(F=4.536, p<0.05$, Table 3$)$. The GP ranged from $80.0 \%$ under $\mathrm{N}_{1} \mathrm{~W}_{2}$ to $94.7 \%$ under $\mathrm{N}_{1} \mathrm{~W}_{3}$. The lowest $\mathrm{T}_{50}$ was observed under $\mathrm{N}_{1} \mathrm{~W}_{1}$, and $\mathrm{T}_{50}$ was 23.7 and $29.9 \%$ lower under $\mathrm{N}_{1} \mathrm{~W}_{1}$ compared with $\mathrm{N}_{1} \mathrm{~W}_{3}$ and $\mathrm{N}_{1} \mathrm{~W}_{3}$, respectively (Figure 3A).

Under $\mathrm{N}_{1}, \mathrm{~T}_{50}$ increased with precipitation. Under $\mathrm{N}_{0}, \mathrm{~T}_{50}$ increased from 8.8 days under $\mathrm{W}_{1}$ to 13.4 days under $\mathrm{W}_{2}$ (Figure 3B). The water conditions experienced by the mother plant affected $\mathrm{T}_{50}$ in the progeny. $\mathrm{T}_{50}$ was lower and higher in the progeny under $\mathrm{W}_{1}$ and $\mathrm{W}_{3}$, respectively, compared with $\mathrm{W}_{2}$. 


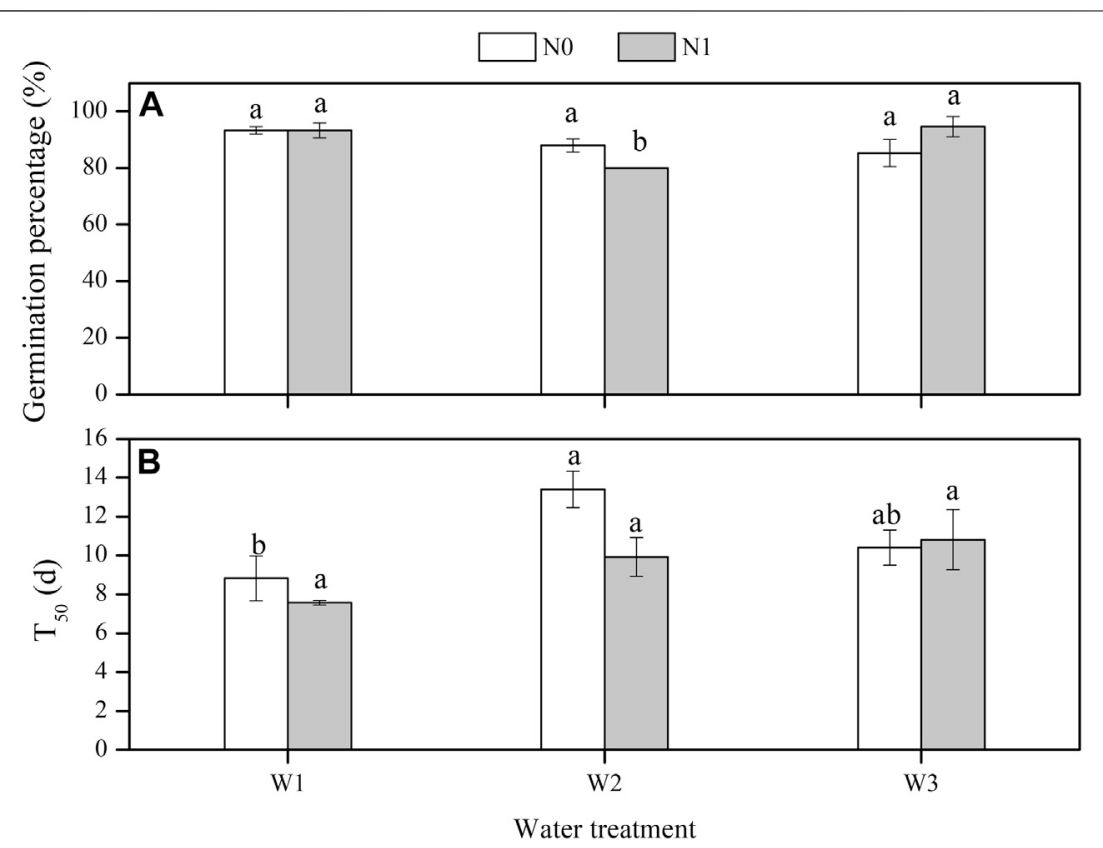

FIGURE 3 | Effects of water and nitrogen on germination percentage and $\mathrm{T}_{50}$ of $L$. chinensis (mean $\pm \mathrm{SE}$ ). $\mathrm{N}_{0}$, control, without $\mathrm{N}$ application; $\mathrm{N}_{1}$, $\mathrm{N}$ applied as urea at $10.5 \mathrm{~g} \mathrm{~N} / \mathrm{m}^{2}$; $\mathrm{W}_{1}, 50 \%$ mean annual precipitation (249 mm) (irrigation amount: $96 \mathrm{ml}$ per pot); $\mathrm{W}_{2}$, mean annual precipitation (498 mm) (irrigation amount: $193 \mathrm{ml}$ per pot); and $W_{3}, 150 \%$ mean annual precipitation $(747 \mathrm{~mm}$ ) (irrigation amount: $289 \mathrm{ml}$ per pot). Different lowercase letters indicate significant differences ( $\mathrm{p}<0.05)$ among water treatments at the same level of $\mathrm{N}$ addition.

\section{DISCUSSION}

\section{Seed Yield}

In this study, the water supply had a major effect on the seed yield (Table 1). The grain number per spike and seed setting rate in $L$. chinensis varied depend on water supply. The increase in the tiller number, heading number, and number grain per spike all contributed to the increase in seed production. Plants under $\mathrm{W}_{3}$ produced 4.6-fold more seeds than plants under $\mathrm{W}_{1}$ with no fertilizer input (Figure 2). The results were consistent with those of Main et al. (2014) showing that the heading number of Gossypium spp. decreases under water deficiency. The heading number of Zoysia japonica, Agropyron cristatum, and Psathyrostachys juncea increases significantly under a suitable level of $\mathrm{N}$ application (Tandoh et al., 2019; Qasim et al., 2020; Zanon et al., 2020). However, our findings are inconsistent with a previous study conducted in Brazil showing that the seed yield of grass was not greatly affected by water (Canto et al., 2020).

The results of this study indicate that water and $\mathrm{N}$ affect the number of germinated seeds of $L$. chinensis in the following year. At the end of the growing season, a large number of buds in the underground bud bank germinated, and the apical meristem of the progeny began to transform from vegetative branches into reproductive branches, many of which reached the spikelet differentiation stage. Hence, water and $\mathrm{N}$ treatment in the previous year has a strong effect on the spikelet differentiation of $L$. chinensis (Ryle, 2010; Taliman et al., 2019).

The results of this study showed that $\mathrm{N}$ addition can improve the grain number per spike and seed yield (Table 1). This might stem from the fact that $\mathrm{N}$ is a major component of nucleic acids and protoplasm. The extra protein produced under $\mathrm{N}$ addition allows the plant leaves to grow larger and hence have a larger surface available for photosynthesis (Zhang et al., 2016). Water can promote nutrient absorption in L. chinensis, which enhances photosynthetic capacity, provides energy for reproductive development, promotes the differentiation of spikes and florets, and reduces the number of aborted spikes and florets. Saeidnia et al. (2018) recorded that water stress reduces the seed yield of Bromus inermis by $38 \%$. A sufficient supply of water and $\mathrm{N}$ can prevent nutrient competition between seeds and other organs after spikelet and floret differentiation, thereby increasing the grain number per spike and seed setting rate (He et al., 2017; Kaisermann et al., 2017; Cohen et al., 2021).

Seed yield is the product of the heading number and the reproductivity of reproductive branches per plant. In this study, water significantly increased the seed yield of $L$. chinensis, which was consistent with the results of previous research (Wang et al., 2010; Chen et al., 2013; Gao et al., 2020). N might promote tillering, the accumulation of dry matter, and seed yield by affecting flower bud development and seed production (Hrdlickova et al., 2011; Wang et al., 2017; Wang et al., 2019; Yang et al., 2019). Additionally, N might be involved in the expression of some flowering genes, as on-off cycles in gene expression are positively correlated with $\mathrm{N}$ fertilization levels; thus, $\mathrm{N}$ fertilization can effectively increase seed yield (Miyazaki et al., 2015).

\section{Seed Germination}

Seed germination is a critical phase in the plant life cycle. Seeds harvested from plants grown in different maternal environments may vary in their ability to germinate under the same germination 
conditions (Nguyen et al., 2021). As shown in Figure 3A, fewer seeds harvested from plants grown under $W_{2}$ germinated compared with those harvested from plants grown under $\mathrm{W}_{1}$ and $\mathrm{W}_{3}$ with $\mathrm{N}$ addition. The shortest $\mathrm{T}_{50}$ in this study was observed under $\mathrm{N}_{1} \mathrm{~W}_{1}$, which indicated that $\mathrm{N}$ application significantly shortened the germination time of seeds. The addition of $\mathrm{N}$ fertilizer to the mother plants promoted the germination of seeds (Alboresi et al., 2005). The mother plant has a substantial influence on seed traits, such as GP (Singh et al., 2017; Geshnizjani et al., 2019). The environmental cues (e.g., soil moisture and nutrients) the mother plant experiences can lead to variation in seed quality even within the same genotype (Van Der Weele et al., 2000).

\section{CONCLUSION}

In conclusion, seed yield was highest when plants had a high tiller number, heading number, and grain number per spike. Therefore, water and $\mathrm{N}$ need to be carefully managed to optimize seed production. The highest seed yield $(7.0 \mathrm{~g} / \mathrm{pot})$ of L. chinensis was observed under $\mathrm{N}_{1} \mathrm{~W}_{3}$. Decreases or increases in precipitation in treatments without $\mathrm{N}$ addition shortened the germination time of the produced seeds.

\section{DATA AVAILABILITY STATEMENT}

The original contributions presented in the study are included in the article/Supplementary Materials, further inquiries can be directed to the corresponding authors.

\section{REFERENCES}

Alboresi, A., Gestin, C., Leydecker, M.-T., Bedu, M., Meyer, C., and Truong, H.-N. (2005). Nitrate, a signal relieving seed dormancy in Arabidopsis. Plant Cel Environ 28, 500-512. doi:10.1111/j.1365-3040.2005.01292.x

Andrade, B. O., Koch, C., BoldriniII, Vélez-Martin, E., Hasenack, H., Hermann, J.M., et al. (2015). Grassland degradation and restoration: a conceptual framework of stages and thresholds illustrated by southern Brazilian grasslands. Natureza \& Conservação 13 (2), 95-104. doi:10.1016/ j.ncon.2015.08.002

Bai, X., Cheng, J. H., and Zheng, S. X. (2014). Ecophysiological responses of Leymus Chinensis to nitrogen and phosphorus additions in a typical steppe[J]. Chin. J. Plant Ecol. 38 (2), 103-115.

Bai, Y., Wu, J., Xing, Q., Pan, Q., Huang, J., Yang, D., et al. (2008). Primary Production and Rain Use Efficiency across a Precipitation Gradient on the Mongolia Plateau. Ecology 89 (8), 2140-2153. doi:10.1890/07-0992.1

Canto, M. W., Pancera, E. J., Neto, A. B., Bremm, C., Vier, P. U., and Costa, A. C. S. (2020). Effects of nitrogen fertilisation and irrigation on seed yield and yield components of signal grass (Urochloa decumbens). Crop Pasture Sci. 71, 294-303. doi:10.1071/cp18369

Chen, J. S., Zhu, R. F., and Zhang, Y. X. (2013). The effect of nitrogen addition on seed yield and yield components of Leymus Chinensis in Songnen Plain, China [J]. J. Soil Sci. Plant Nutr. 13, 329-339.

Cohen, I., Zandalinas, S. I., Huck, C., Fritschi, F. B., and Mittler, R. (2021). Metaanalysis of drought and heat stress combination impact on crop yield and yield components. Physiol. Plantarum 171 (1), 66-76. doi:10.1111/ppl.13203

Duan, N., Li, Q. H., and Duo, P. Z. (2019). Plant response to atmospheric nitrogen deposition: a research review[J]. World For. Res. 32 (4), 6-11.

\section{AUTHOR CONTRIBUTIONS}

D-DZ conceived and designed the experiments, performed the experiments, analyzed the data, prepared figures and/or tables, authored or reviewed drafts of the paper, and approved the final draft. H-YM conceived and designed the experiments, authored or reviewed drafts of the paper, and approved the final draft. LW conceived and designed the experiments, authored or reviewed drafts of the paper, and approved the final draft. S-YL performed the experiments, prepared figures and/or tables, and approved the final draft. $\mathrm{W}-\mathrm{WQ}, \mathrm{M}-\mathrm{YM}$ and J-BX performed the experiments, authored or reviewed drafts of the paper, and approved the final draft.

\section{FUNDING}

This research was supported by grants from the National Natural Science Foundation of China (41977424; 41771058), the National Key Basic Survey of Resources (2015FY110500), the Provincial Natural Science Foundation of Jilin (20200201026JC) and the Strategic Priority Research Program of the Chinese Academy of Sciences, Grant No. XDA28110300.

\section{SUPPLEMENTARY MATERIAL}

The Supplementary Material for this article can be found online at: https://www.frontiersin.org/articles/10.3389/fenvs.2021.704097/ full\#supplementary-material

Farooq, M., Basra, S. M. A., Ahmad, N., and Hafeez, K. (2005). Thermal Hardening: A New Seed Vigor Enhancement Tool in Rice. J. Integr. Plant Biol. 47, 187-193. doi:10.1111/j.1744-7909.2005.00031.x

Gajić, B., Kresović, B., and Tapanarova, A. (2018). Effect of irrigation regime on yield, harvest index and water productivity of soybean grown under different precipitation conditions in a temperate environment[J]. Agric. Water Manag. 210, 224-231.

Gao, S., Wang, J., Knops, J. M. H., and Wang, J. (2020). Nitrogen addition increases sexual reproduction and improves seedling growth in the perennial rhizomatous grass Leymus chinensis. BMC Plant Biol. 20, 106. doi:10.1186/ s12870-020-2307-8

Geshnizjani, N., Sarikhani Khorami, S., Willems, L. A. J., Snoek, B. L., Hilhorst, H. W. M., and Ligterink, W. (2019). The interaction between genotype and maternal nutritional environments affects tomato seed and seedling quality. J. Exp. Bot. 70 (10), 2905-2918. doi:10.1093/jxb/erz101

Ghaderi-Far, F., Gherekhloo, J., and Alimagham, M. (2010). Influence of environmental factors on seed germination and seedling emergence of yellow sweet clover (Melilotus officinalis). Planta Daninha 28, 463-469. doi:10.1590/s0100-83582010000300002

Han, D., Wang, G., Xue, B., Liu, T., A, Y., and Xu, X. (2018). Evaluation of semiarid grassland degradation in North China from multiple perspectives. Ecol. Eng. 112, 41-50. doi:10.1016/j.ecoleng.2017.12.011

He, J., Jin, Y., Du, Y.-L., Wang, T., Turner, N. C., Yang, R.-P., et al. (2017). Genotypic Variation in Yield, Yield Components, Root Morphology and Architecture, in Soybean in Relation to Water and Phosphorus Supply. Front. Plant Sci. 8, 1499. doi:10.3389/fpls.2017.01499

Hrdlickova, J., Hejcman, M., and Kristalova, V. (2011). Production, size, and germination of broad-leaved dock seeds collected from mother plants grown under different nitrogen, phosphorus, and potassium supplies. Weed Biol. Manag. 11, 190-201. 
Huang, L., Liang, Z., Suarez, D. L., Wang, Z., and Wang, M. (2019). Effects of continuous nitrogen application on seed yield, yield components and nitrogen-use efficiency of Leymus chinensis in two different saline-sodic soils of Northeast China. Crop Pasture Sci. 70 (4), 373-383. doi:10.1071/ cp18274

Islam, S., Rahman, M. M., and Naidu, R. (2018). Impact of water and fertilizer management on arsenic bioaccumulation and speciation in rice plants grown under greenhouse conditions. Chemosphere 214, 606-613. doi:10.1016/ j.chemosphere.2018.09.158

Kaisermann, A., Vries, F. T., Griffiths, R. I., and Bardgett, R. D. (2017). Legacy effects of drought on plant-soil feedbacks and plant-plant interactions. New Phytol. 215 (4), 1413-1424. doi:10.1111/nph.14661

Kunstler, G., Falster, D., Coomes, D. A., Hui, F., Kooyman, R. M., Laughlin, D. C., et al. (2016). Plant functional traits have globally consistent effects on competition. Nature 529, 204-207. doi:10.1038/nature16476

Li, Q., Song, Y., Li, G., Yu, P., Wang, P., and Zhou, D. (2015). Grass-legume mixtures impact soil $\mathrm{N}$, species recruitment, and productivity in temperate steppe grassland. Plant Soil 394, 271-285. doi:10.1007/ s11104-015-2525-2

Liu, X., Li, M., Guo, P., and Zhang, Z. (2019). Optimization of water and fertilizer coupling system based on rice grain quality. Agric. Water Manag. 221, 34-46. doi:10.1016/j.agwat.2019.04.009

Ma, H. Y., Lv, B. S., and Yang, H. Y. (2012). Responses of seed germination of Leymus Chinensis to environmental factors in degraded grassland on Songnen Plain in China[J]. Chin. J. Plant Ecol. 36 (8), 812-818.

Ma, H. Y., Wu, H. T., and Ooi, M. K. J. (2018). Within population variation in germination response to smoke cues: convergent recruitment strategies and different dormancy types[J]. Plant Soil 427 (1), 281-290.

Main, C. L., Barber, L. T., and Boman, R. K. (2014). Effects of nitrogen and planting seed size on cotton growth, development, and yield[J]. Agron. J. 105 (6), 1853-1859.

Man, J., Deng, B., and Zhang, J. L. (2016). Effects of litter covering on typical grassland vegetation and soil characteristics in inner Mongolia[J]. Chin. J. Grassland 38 (2), 59-64.

Miyazaki, Y., Maruyama, Y., Chiba, Y., Kobayashi, M. J., Joseph, B., Shimizu, K. K., et al. (2015). Nitrogen as a key regulator of flowering in Fagus crenata: understanding the physiological mechanism of masting by gene expression analysis. Ecol. Lett. 17 (10), 1299-1309. doi:10.1111/ele.12338

Nerlekar, A. N., and Veldman, J. W. (2020). High plant diversity and slow assembly of old-growth grasslands. Proc. Natl. Acad. Sci. USA. 117 (31), 18550-18556. doi:10.1073/pnas.1922266117

Nguyen, C. D., Chen, J., Clark, D., Perez, H., and Huo, H. (2021). Effects of Maternal Environment on Seed Germination and Seedling Vigor of Petunia $\times$ hybrida under Different Abiotic Stresses. Plants 10 (3), 581. doi:10.3390/ plants10030581

Ochoa-Hueso, R., Bell, M. D., and Manrique, E. (2014). Impacts of increased nitrogen deposition and altered precipitation regimes on soil fertility and functioning in semiarid Mediterranean shrublands. J. Arid Environments 104, 106-115. doi:10.1016/j.jaridenv.2014.01.020

Pan, Q. M., Bai, Y. F., Han, X. G., and Yang, J. C. (2005). Effects of nitrogen additions on a Leymus Chinensis population in typical steppe of Inner Mongolia. Acta Phytoecologica Sinica 29, 311-317.

Qasim, M., Amin, M., and Sarwar, M. K. S. (2020). Effect of different biochemical traits on seed cotton yield: An application of liu linear regression[J]. J. Anim. Plant Sci. 30 (6), 1533-1539. doi:10.36899/japs.2020.6.0174

Ren, A., Wei, M., Yin, L., Wu, L., Zhou, Y., Li, X., et al. (2014). Benefits of a fungal endophyte in Leymus Chinensis depend more on water than on nutrient availability. Environ. Exp. Bot. 108, 71-78. doi:10.1016/ j.envexpbot.2013.11.019

Ryle, G. J. A. (2010). The influence of data of origin of the shoot and level of nitrogen on ear size in three perennial grasses[J]. Ann. Appl. Biol. 53 (2), 311-323.

Saeidnia, F., Majidi, M. M., and Mirlohi, A. (2018). Genetic potential to improve seed and forage yield simultaneously in smooth bromegrass under water deficit conditions. Euphytica 214 (2), 42-55. doi:10.1007/s10681018-2121-7

Shen, H. H., Zhu, Y. K., and Zhao, X. (2016). Analysis of current grassland resources in China[M]. Sci. China Press 61 (2), 139-154.
Shi, Y., Gao, S., Zhou, D., Liu, M., Wang, J., Knops, J. M. H., et al. (2017). Fall nitrogen application increases seed yield, forage yield and nitrogen use efficiency more than spring nitrogen application in Leymus chinensis, a perennial grass. Field Crops Res. 214, 66-72. doi:10.1016/ j.fcr.2017.08.022

Singh, J., Clavijo Michelangeli, J. A., Gezan, S. A., Lee, H., and Vallejos, C. E. (2017). Maternal Effects on Seed and Seedling Phenotypes in Reciprocal F1 Hybrids of the Common Bean (Phaseolus vulgaris L.). Front. Plant Sci. 8, 42. doi:10.3389/ fpls.2017.00042

Taliman, N. A., Dong, Q., Echigo, K., Raboy, V., and Saneoka, H. (2019). Effect of Phosphorus Fertilization on the Growth, Photosynthesis, Nitrogen Fixation, Mineral Accumulation, Seed Yield, and Seed Quality of a Soybean Low-Phytate Line. Plants 8 (5), 119. doi:10.3390/plants8050119

Tandoh, S., Coulman, B., and Biligetu, B. (2019). Assessment of crested wheatgrass (Agropyron cristatum L.) accessions with different geographical origins for agronomic and phenotypic traits and nutritive value. Euphytica 215 (10), 161. doi:10.1007/s10681-019-2476-4

Van Der Weele, C. M., Spollen, W. G., Sharp, R. E., and Baskin, T. I. (2000). Growth of Arabidopsis thaliana seedlings under water deficit studied by control of water potential in nutrient-agar media. J. Exp. Bot. 51, 1555-1562. doi:10.1093/jexbot/ 51.350 .1555

Wang, J., Knops, J. M. H., Brassil, C. E., and Mu, C. (2017). Increased productivity in wet years drives a decline in ecosystem stability with nitrogen additions in arid grasslands. Ecology 98 (17), 1779-1786. doi:10.1002/ecy.1878

Wang, J. F., Shi, Y. J., and Ao, Y. N. (2019). Summer drought decreases L. chinensis productivity through constraining the bud, tiller and shoot production[J]. J. Agron. Crop Sci. 205, 54-61. doi:10.1111/jac.12354

Wang, J. F., Xie, J. F., Zhang, Y. T., Gao, S., Zhang, J. T., and Mu, C. S. (2010). Methods to Improve Seed Yield of Leymus chinensis based on Nitrogen Application and Precipitation Analysis. Agron. J. 102, 277-281. doi:10.2134/ agronj2009.0254

Wang, J., Li, X., Gao, S., Li, Z., and Mu, C. (2013). Impacts of Fall Nitrogen Application on Seed Production in Leymus chinensis, a Rhizomatous Perennial Grass. Agron.j. 105 (5), 1378-1384. doi:10.2134/agronj2013.0063

Wang, X., Guo, T., Wang, Y., Xing, Y., Wang, Y., and He, X. (2020). Exploring the optimization of water and fertilizer management practices for potato production in the sandy loam soils of Northwest China based on PCA. Agric. Water Manag. 237, 106180. doi:10.1016/j.agwat.2020.106180

Wick, A. F., Geaumont, B. A., Sedivec, K. K., and Hendrickson, J. R. (2016). Grassland Degradation. Grassland Degradation[j]. Biol. Environ. Hazards, Risks Disasters 8, 257-276. doi:10.1016/b978-0-12-394847-2.00016-4

Wu, Z., Dijkstra, P., Koch, G. W., Peñuelas, J., and Hungate, B. A. (2011). Responses of terrestrial ecosystems to temperature and precipitation change: a meta-analysis of experimental manipulation. Glob. Change Biol. 17, 927-942. doi:10.1111/j.1365-2486.2010.02302.x

Yang, G. J., Lü, X. T., Stevens, C. J., Zhang, G. M., Wang, H. Y., Wang, Z. W., et al. (2019). Mowing mitigates the negative impacts of $\mathrm{N}$ addition on plant species diversity. Oecologia 189 (3), 769-779. doi:10.1007/s00442-019-04353-9

Yang, Y. F. (1989). The watering and fertilizing effects to characters of ear organ and grain yield on population of Aneurolepidium chinensis[J]. Chin. J. Grassland 1, 11-15.

Zanon, M. E., Mazzini-Guedes, R. B., Ferraz, M. V., Bezerra, A. K. D., Muniz, A. C. C., and Pivetta, K. F. L. (2020). Temperature, potassium nitrate, substrate, and harvesting time on the germination of zoysia grass seeds. Ornam. Hortic. 26 (1), 51-56. doi:10.1590/2447-536x.v26i1.2043

Zhang, H. Q., Zhang, H. M., and Liang, Y. S. (2016). Research progress of nitrate in plant transport mechanism[J]. Plant Physiol. J. 52 (2), 141-149.

Zhao, D. D., Ma, H. Y., and Yang, Li. (2019). Effects of water and nutrient addition on functional traits andaboveground biomass of Leymus Chinensis [J]. Chin. J. Plant Ecol. (06), 501-511. doi:10.17521/cjpe.2019.0041

Zhao, H., Liu, S., and Dong, S. (2015). Analysis of vegetation change associated with human disturbance using modis data on the rangelands of the qinghaitibet plateau[J]. Rangeland J. 1 (37), 77. doi:10.1071/rj14061

Zhao, Y., Liu, Z., and Wu, J. (2020). Grassland ecosystem services: a systematic review of research advances and future directions[J]. Landscape Ecol., 1-22.

Zhou, C., and Yang, Y. F. (2006). Allometry regulation of leaf module for two ecotypes of Leymus Chinensis in Songnen Plain, China[J]. Acta Prataculturae Sinica 15 (5), 76-81. 
Zhou, M., Yang, Q., Zhang, H., Yao, X., Zeng, W., and Wang, W. (2020). Plant community temporal stability in response to nitrogen addition among different degraded grasslands. Sci. Total Environ. 729, 138886-138889. doi:10.1016/ j.scitotenv.2020.138886

Conflict of Interest: The authors declare that the research was conducted in the absence of any commercial or financial relationships that could be construed as a potential conflict of interest.

Publisher's Note: All claims expressed in this article are solely those of the authors and do not necessarily represent those of their affiliated organizations, or those of the publisher, the editors and the reviewers. Any product that may be evaluated in this article, or claim that may be made by its manufacturer, is not guaranteed or endorsed by the publisher.

Copyright $\odot 2021$ Zhao, Ma, Wang, Li, Qi, Ma and Xia. This is an open-access article distributed under the terms of the Creative Commons Attribution License (CC $B Y)$. The use, distribution or reproduction in other forums is permitted, provided the original author(s) and the copyright owner(s) are credited and that the original publication in this journal is cited, in accordance with accepted academic practice. No use, distribution or reproduction is permitted which does not comply with these terms. 